\title{
Laporan Kasus Hemofilia A dengan Komplikasi Epilepsi Pasca Perdarahan Intrakranial
}

\author{
Irma Rochima Puspita, Pustika Amalia, Irawan Mangunatmadja
}

Seorang bayi laki-laki berumur 9 bulan dengan hemofilia A dirawat di RS Dr. Ciptomangunkusumo Jakarta epilepsi pasca perdarahan intrakranial akibat trauma di kepala. Adanya perdarahan intrakranial dipastikan oleh pemeriksaan CT Scan kepala. Diagnosis hemofilia A ditegakkan pada waktu penderita mengalami perdarahan intrakranial, sedangkan diagnosis epilepsi ditegakkan berdasarkan hasil pemeriksaan EEG. Pengobatan yang diberikan kepada penderita pada saat terjadinya perdarahan intrakranial ialah konsentrat faktor VIII karena penderita alergi terhadap kriopresipitat. Tindakan bedah tidak dilakukan karena orang tua pasien menolak. Asam valproat diberikan untuk pengobatan epilepsi.

Kata kunci : hemofilia, perdarahan intrakranial, pencitraan neurologis, epilepsi, EEG

$\mathcal{H}$ emofilia adalah penyakit gangguan pembekuan darah akibat defisiensi faktor pembekuan darah yang bersifat heriditer. Hemofilia A disebabkan defisiensi faktor VIII, sedangkan hemofilia B akibat defisiensi faktor IX. Penyakit ini diturunkan dengan cara $x$-linked resesif. ${ }^{1-4}$ Meskipun demikian sekitar 30\% kelainan ini akibat mutasi spontan pada ujung lengan panjang kromosom $\mathrm{x} \cdot{ }^{2,3,5-7}$

Perdarahan intrakranial merupakan salah satu penyebab kematian pasien hemofilia. Angka kejadian perdarahan intrakranial pada pasien hemofilia adalah

\footnotetext{
Alamat korespondensi:

Dr Pustika Amalia, Sp.A(K)

Divisi Hematologi. Departemen Ilmu Kesehatan Anak FKUI-RSCM. Jl. Salemba no. 6, Jakarta 10430.

Telepon: 021-3907744, 31901170 Fax.021-3913982.

Dr. Irma Rochima Puspita. PPDS IKA, FKUI
}

2,2\%-13,8\% dengan angka kematian sekitar 25\%$30 \% .{ }^{7,8,9}$ Penyebab tersering perdarahan intrakranial adalah trauma kepala 50\%, namun pada pasien hemofilia berat dapat terjadi perdarahan intrakranial tanpa riwayat trauma. ${ }^{6,8}$ Pasien hemofilia A di RSCM yang mengalami perdarahan intrakranial adalah 6 pasien $(5,3 \%)$. Perdarahan intrakranial dapat mengakibatkan gejala sisa neurologis berupa epilepsi, retardasi mental, kesulitan belajar dan kelemahan motorik. $^{7-12}$

Tujuan laporan kasus ini adalah untuk mendiskusikan diagnosis dan tata laksana hemofilia A dengan komplikasi epilepsi pasca perdarahan intrakranial.

\section{Kasus}

Seorang anak laki-laki, T, umur 9 bulan, datang ke Poliklinik RSCM pada tanggal 16 April 2005 dengan keluhan kejang berulang sejak 3 hari sebelum masuk 
rumah sakit. Pasien dirujuk oleh dokter RSS G anak dengan diagnosis hemofilia dan epilepsi pasca perdarahan intrakranial.

Berdasarkan alloanamnesis dengan ibu pasien didapatkan keterangan bahwa tiga minggu sebelumnya (29 Maret 2005) pasien mengalami kejang pada ekstremitas kiri, mata melihat ke kanan atas selama 2 menit. Pasca kejang pasien masih sadar, tidak didapatkan demam maupun muntah. Tiga jam sebelum kejang, kepala pasien terbentur tepi tempat tidur. Pada pemeriksaan penunjang di RSS G didapatkan hemoglobin 10,1 g/dL, leukosit 9.500/ $\mu \mathrm{L}$, trombosit $550.000 / \mu \mathrm{L}$, masa perdarahan 2 menit (1-6 menit), masa pembekuan 13 menit (1013 menit), prothrombin time (PT) 23 detik (kontrol: 17 detik), partial thromboplastin time (PTT) 80 detik (kontrol: 36 detik). Pada pemeriksaan computed tomographic scan (CT scan) kepala tanpa kontras (29 Maret 2005) didapatkan adanya perdarahan subdural dan perdarahan epidural lobus parietotemporofrontal kanan, perdarahan subarakhnoid fisura interhemisfer anterior dan posterior, tampak pendorongan garis tengah ke kiri, tidak didapatkan fraktur tulang kepala dan kulit kepala tampak baik. Pasien didiagnosis perdarahan intrakranial diduga akibat hemofilia. Pengobatan yang telah dilakukan antara lain pemberian kriopresipitat 400 U (5 kantong). Pada saat pertengahan pemberian kriopresipitat terjadi reaksi alergi, sehingga kriopresipitat diganti dengan konsentrat faktor VIII 500 U tiap 12 jam selama 5 hari, dilanjutkan $250 \mathrm{U}$ tiap 12 jam selama 5 hari berikut dan pemberian antikonvulsan. Pada saat itu dokter bedah saraf merencanakan operasi kepala, keluarga pasien menolak. Pada pemeriksaan ulang setelah selesai pemberian konsentrat faktor VIII selama 10 hari (8 April 2005), didapatkan kadar hemoglobin $11,4 \mathrm{~g} / \mathrm{dL}$,

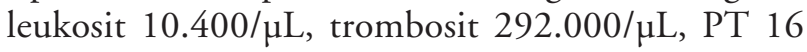
detik (kontrol: 17 detik), PTT 39 detik (kontrol: 36 detik). Hasil pemeriksaan CT scan kepala ulang (8 April 2005) adalah perdarahan subdural dan perdarahan epidural lobus parietotemporofrontal kanan serta perdarahan subarakhnoid berkurang dibandingkan dengan $C T$ scan kepala sebelumnya dan tidak tampak pendorongan garis tengah. Pada hari perawatan kesebelas kondisi klinis pasien baik, tidak didapatkan kejang maupun kelemahan ekstremitas kiri dan pasien diijinkan pulang dari RSSG.

Tiga hari sebelum masuk RSCM (16 April 2005) pasien kejang berulang 2-3 kali/hari dengan interval
8-10 jam. Pada saat kejang pasien tidak sadar, mata melihat ke kanan atas dan kebiruan di sekitar mulut, kurang lebih selama satu menit, pasca kejang pasien sadar. Tidak didapatkan riwayat trauma kepala lagi maupun demam. Pada kepala tidak ditemukan memar, tidak tampak perdarahan pada mata dan telinga kiri. Muntah tiga kali perhari, tidak menyemprot dan isi makanan. Pasien dibawa lagi ke RSS G. Pada saat di RSS G pasien sadar, tidak didapatkan kejang maupun kelemahan pada ekstremitas. Dilakukan pemeriksaan electroencephalography (EEG) dengan hasil normal. Pasien didiagnosis epilepsi pasca perdarahan intrakranial dan tersangka hemofilia. Pasien diberi pengobatan asam valproat $2 \times 75 \mathrm{mg}$ peroral, fenitoin $2 \times 30 \mathrm{mg}$ peroral, pirasetam $2 \times 125 \mathrm{mg}$ peroral. Pasien kemudian dirujuk ke RSCM karena setelah pemberian antikonvulsan selama tiga hari masih didapatkan kejang berulang.

Pasien merupakan anak ketiga dari 3 bersaudara. Riwayat kehamilan ibu normal. Pasien lahir spontan, cukup bulan, ditolong oleh dokter, berat lahir 2700 gram, panjang lahir $48 \mathrm{~cm}$ dan langsung menangis. Riwayat perkembangan pasien normal. Sejak usia 4 bulan didapatkan riwayat sering memar pada ekstremitas dan setelah imunisasi didapatkan bengkak dan kebiruan yang lama hilang di sekitar bekas suntikan. Tidak didapatkan riwayat kejang demam maupun kejang tanpa demam dalam keluarga.

Pada pemeriksaan fisis di RSCM pada tanggal 16 April 2005 didapatkan anak laki-laki berusia 9 bulan dengan berat badan $8,4 \mathrm{~kg}$, panjang badan $70 \mathrm{~cm}$. Lingkar kepala $43 \mathrm{~cm}$ (normal). Ubun-ubun besar datar dengan ukuran $1 \times 1,5 \mathrm{~cm}$. Anak tampak sadar. Laju nadi sama dengan laju denyut jantung $92 \mathrm{kali} /$ menit, laju pernapasan $24 \mathrm{kali} / \mathrm{menit}$, suhu aksila $36,2^{\circ} \mathrm{C}$. Tidak pucat, pupil bulat, isokor dengan diameter $3 \mathrm{~mm}$, refleks cahaya secara langsung maupun tidak langsung didapatkan positif normal. Tidak didapatkan paresis saraf kranial pada wajah. Tidak didapatkan tanda rangsang meninggal. Paru dan jantung normal, Aldomen normal. Pada pemeriksaan alat gerak didapatkan akral yang hangat dengan perfusi perifer yang cukup, refleks bisep $+/+$, refleks trisep +/ + , refleks patela $+/+$, refleks Achilles +/+, tidak dijumpai klonus maupun refleks patologis. Pemeriksaan Babinsky negatif, Kernig $>135^{\circ}$ dan Laseque $>70^{\circ}$. Pemeriksaan motorik 5/5/5/5 pada keempat ekstremitas. Pemeriksaan aktivitas faktor VIII menunjukkan hasil rendah yaitu 2,4\%. Hasil EEG 
ulang didapatkan gambaran gelombang fokal epileptiform pada lobus temporalis kanan.

Pasien didiagnosis hemofilia A sedang dan epilepsi parsial kompleks. Pasien ditatalaksana dengan konsentrat faktor VIII 250 U per 12 jam selama tiga hari. Dosis asam valproat dinaikkan menjadi 3 x 100 mg peroral. Tiga hari setelah terapi tidak didapatkan kejang kembali dan pasien dipulangkan.

\section{Diskusi}

Hemofilia yang diderita pasien kemungkinan akibat mutasi spontan karena tidak didapatkan riwayat hemofilia dalam keluarga. Kelainan ini menyebabkan pasien mudah mengalami perdarahan. Perdarahan pada hemofilia dapat berupa perdarahan pada sendi, otot, kulit, mukosa, saluran cerna dan intrakranial. Angka kejadian perdarahan intrakranial pada pasien hemofilia berkisar 2,2-13,8\% dengan angka mortalitas sebesar $25-30 \%{ }^{7,8,9}$ Faktor prediksi tingginya angka kematian akibat perdarahan intrakranial adalah nilai Glasgow Coma Scale (GCS) yang rendah yaitu kurang dari 8 dan perdarahan yang luas. ${ }^{9,10}$

Perdarahan intrakranial pada pasien hemofilia sedang selalu didahului trauma kepala. Namun pada pasien hemofilia berat perdarahan intrakranial dapat terjadi tanpa riwayat trauma kepala. ${ }^{7,13}$ Perdarahan dapat terjadi di berbagai tempat seperti di subdural, epidural, subarakhnoid maupun intraserebral. ${ }^{713}$ Pada pasien ini sebelum terjadi perdarahan intrakranial terdapat trauma kepala.

Pada pasien dengan perdarahan intrakranial, kelainan pembekuan darah kadang-kadang baru diketahui saat dilakukan skrining terhadap pembekuan darah setelah evaluasi hasil CT scan kepala. ${ }^{8,13-14}$ Bray dan $\operatorname{Luban}^{8}$ melaporkan bahwa bayi dengan perdarahan intrakranial didapatkan peningkatan nilai PTT dan defisiensi faktor VIII yang baru diketahui sebelum dilakukan operasi kepala. Pada pasien ini setelah hasil CT scan kepala menunjukkan adanya perdarahan intrakranial, dilakukan pemeriksaan faktor pembekuan darah dengan hasil ditemukan peningkatan nilai PTT, sedangkan nilai PT dan hitung trombosit normal. Pada pasien ini hasil pemeriksaan faktor pembekuan darah menunjukkan adanya penurunan aktivitas faktor VIII.

Pemeriksaan pencitraan mempunyai peran penting dalam menegakkan diagnosis perdarahan intrakranial. ${ }^{7-}$ 10, 12-19 Pasien dengan riwayat trauma kepala yang disertai penurunan kesadaran, kejang fokal, paresis, nyeri kepala dan muntah yang persisten, mempunyai indikasi kuat untuk dilakukan pencitraan kepala untuk mengetahui adanya perdarahan intrakranial. ${ }^{18}$ Pemeriksaan yang sering digunakan adalah foto kepala, CT scan kepala dan Magnetic Resonance imagung (MRI) kepala. ${ }^{7-10,12-19}$ Foto kepala merupakan pemeriksaan yang relatif paling mudah tetapi mempunyai sensitifitas dan spesifitas yang bervariasi, sehingga sangat sulit untuk menarik suatu kesimpulan. Pemeriksaan CT scan kepala direkomendasikan pada pasien dengan penurunan kesadaran, kejang fokal, GCS kurang dari 13, fraktur tulang kepala. ${ }^{15-19}$ Pemeriksaan $M R I$ merupakan pemeriksaan yang lebih akurat dibandingkan $C T$ scan kepala karena dapat menggambarkan kelainan pada otak lebih rinci. ${ }^{19}$

Prinsip tata laksana pasien hemofilia dengan perdarahan intrakranial adalah menghentikan proses perdarahan dan mencegah komplikasi akibat perdarahan intrakranial. Pasien hemofilia dengan riwayat trauma kepala, meskipun trauma kepala ringan harus dirawat dan segera mendapatkan terapi. ${ }^{7,8,13}$ Terapi yang diberikan adalah pemberian faktor pembekuan dengan tujuan utama adalah meningkatkan kadar faktor pembekuan sampai $100 \%$. Pada pasien hemofilia A jika hasil pemeriksaan CT scan kepala terbukti adanya perdarahan maka kadar faktor VIII harus terus dipertahankan sampai 100\% dengan pengawasan yang ketat. ${ }^{2-4,7,13}$ Preparat yang mengandung faktor VIII dapat berupa kriopresipitat, konsentrat faktor VIII atau rekombinan faktor VIII yang diberikan setiap 12-24 jam. ${ }^{2-4,7,8}$ Dosis pemberian konsentrat faktor VIII adalah $50 \mathrm{U} / \mathrm{KgBB}$ akan menaikkan aktivitas faktor VIII menjadi 100\%. Lama pemberian adalah 10-14 hari atau sampai terjadi resolusi perdarahan intrakranial akan memberikan hasil yang baik. ${ }^{3,7,8,13}$ Kinney $\mathrm{dkk}^{20}$ melaporkan pasien hemofilia A dengan pemberian konsentrat faktor VIII selama 14 hari menunjukkan resolusi perdarahan intrakranial dan tidak didapatkan gejala sisa neurologis. Pada pasien ini pemberian konsentrat faktor VIII pada awal terapi diberikan hanya selama 10 hari meskipun hasil pemeriksaan $C T$ scan kepala ulang masih didapatkan perdarahan. Pada saat di RSCM, pasien diberikan kembali konsentrat faktor VIII karena hasil CT scan kepala terakhir masih menunjukkan adanya perdarahan dan kejang berulang selama tiga hari.

Pembedahan pada pasien hemofilia dengan perdarahan intrakranial dilakukan jika terjadi proses 
desak ruang yang progresif.9,13,15,16 Eisyter $\mathrm{dkk}^{7}$ melaporkan dari 65 pasien hemofilia dengan perdarahan intrakranial terdapat 20 pasien (31\%) yang dilakukan operasi dan pemberian faktor pembekuan. ${ }^{7,13,15,16}$ Hasil CT scan kepala pasien ini pada awal perawatan menunjukkan perdarahan luas dan dan proses desak ruang, sehingga pasien direncanakan operasi namun karena orang tua pasien menolak maka pasien hanya diberikan faktor pembekuan sampai sepuluh hari. Kondisi klinis pasien selama perawatan membaik dan hasil pemeriksaan CT scan kepala ulang menunjukkan perdarahan yang berkurang.

Trauma kepala yang berat sering mengakibatkan gejala sisa neurologis yaitu epilepsi, gangguan kognitif, gangguan perilaku, gangguan bicara maupun gangguan motorik. ${ }^{7,15,16}$ Mahoney $\mathrm{dkk}^{21}$ melaporkan bahwa anak dengan trauma kepala berat, $62 \%$ tanpa gejala sisa neurologis, sedangkan 20\% dengan gangguan tingkah laku dan 18\% dengan gangguan kognitif maupun motorik. Pada pasien ini pasca perdarahan intrakranial didapatkan gejala sisa epilepsi. Pasien hemofilia dengan komplikasi epilepsi pasca perdarahan intrakranial rutin diberikan antikonvulsan sampai 2 tahun bebas kejang., ${ }^{7,14}$

Prognosis pasien hemofilia dengan perdarahan intrakranial yang ditatalaksana dengan tepat adalah baik. Pasien ini mempunyai prognosis baik karena meskipun mendapat komplikasi epilepsi, tetapi dengan pemberian antikonvulsan yang tepat dapat mengontrol kejang. Perlu pemantauan yang terus menerus untuk melihat dampak panjang akibat perdarahan intrakranial dan efek samping pemberian faktor pembekuan maupun antikonvulsan.

\section{Daftar Pustaka}

1. Mannucci PM, Tuddenham EG. The hemophiliasfrom royal genes to gene therapy. $\mathrm{N}$ Engl J Med 2001;344:1773-9.

2. Ljung R, Vournas SA, Aurbeger KK, Chambost H, Claeyssens S, Vangeet C, dkk. Treatment of children with haemophilia in Europe: a survey of 20 centers in 16 countries. Haemophilia 2000;6:619-24.

3. Dimichele D, Naufeld EJ. Hemophilia: a new approach to an old disease. Hematol Oncol Clin North Am 1998;12:1315-37.

4. Hoyer L. Haemophilia A. N Engl J Med 1994;330: 38-49.

5. Gilles AR, Rivard GE, Teitel J, Walker I. Suggestion for the management of factor VIII inhibitors. Haemophilia 1997;10:1-16.

6. Walker IR, Julian JA. Causes of death in Canadian with haemophilia 1980-1995. Haemophilia 1998;4:714-20.

7. Eyster E, Gill FM, Blatt PM, Hilgartner MW, Ballard JO, Kinney TR. Central Nervous System Bleeding in hemophiliacs. Blood 1978;51:1179-88.

8. Bray GL, Luban NLC. Hemophilia presenting with intracranial haemorrhage. An approach to the infant with intracranial bleeding and coagulopathy. Am J Dis Child 1987;141:1215-7.

9. Qureshi AI, Tuhrim S, Broderick JP, Batjer HH, Hondo $\mathrm{H}$, Hanley DF. Spontaneous intracerebral haemorrhage. N Engl J Med 2001;344:1450-60.

10. Faught F, Peters D, Bartolucci, Moore L, Miller PC. Seizure after primary intracerebral haemorrhage. Neurology 1989;39:1089-93.

11. Chang BS, Lowenstein DH. Epilepsy. N Engl J Med 2003;349:1257-66.

12. Sung CY, Chu NS. Epileptic seizures in intracerebral haemorrhage. J Neurol Neurosurg Psychiatry 1989;52: 1273-6.

13. Andes WA, Wulff K, Smith B. Head trauma in hemophilia: a prospective study. Arch Intern Med 1984;144: 1981-3.

14. Vorstman EBA, Anslow P, Keeling DM, Haythornthwait $\mathrm{G}$, Bilolikar H, McShane. Brain haemorrhage in five infants with coagulopathy. Arch Dis Child 2003;88: 1119-21.

15. Gedeit R. Head injury. Pediatrics 2001;22:118-24.

16. Homer CJ, Kleinman L. Technical Report: minor head injury in children. Pediatrics 1999;104:p.e78. (electronic article)

17. American Academy of Pediatrics. The management of minor closed head injury in children. Pediatrics 1999; 104:1407-1.

18. Sharma S, Riviello JJ, Harper MB, Baskin MN. The role of emergent neuroimaging in children with newonset afebrile seizure. Pediatrics 2003;111:1-5.

19. Reed MJ, Browning JG, Wilkinson AG, Beattie. Can we abolish skull x-ray for head injury? Arch Dis Child 2005;90:859-64.

20. Kinney TR, Zimmerman RA, Butler RB, Gill FM. Computerized tomography in management of intracranial bleeding in hemophilia. J Pediatr 1977;91:31-5.

21. Mahoney WJ, D'souza BJ, Haller JA, Rogers MC, Epstein MH, Freeman JM. Long-term outcome of children with severe head trauma and prolonged coma. Pediatrics 1983;71:756-62. 